\title{
THE IMAGE AND SUSTAINABILITY
}

OF TOURISM DESTINATIONS

\section{PROCEEDINGS OF}

11th INTERNATIONAL TOURISM CONGRESS

2019

ABSTRACT BOOK

FUNCHAL | PORTUGAL

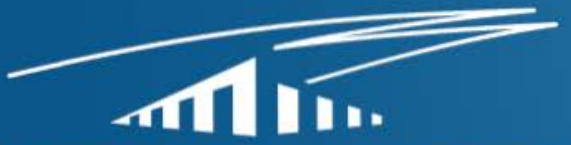

UNIVERSIDADE da MADEIRA

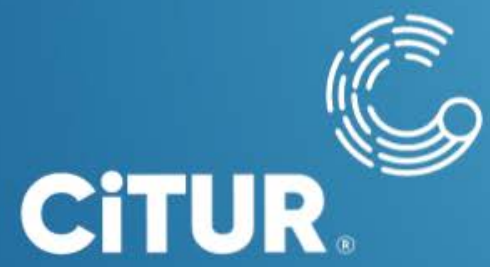




\section{Editing and Property}

CiTUR - Centre for Tourism Research, Development and Innovation www.citur-tourismresearch.com

\section{Editorial Board}

Paulo Almeida | João Paulo Jorge | João Costa

School of Tourism and Maritime Technology

\section{Graphic Design and Layout}

João Costa

C) All rights reserved - CiTUR - Centre for Tourism Research, Development and Innovation November 2019 


\section{ORGANIZING COMMITTEE}

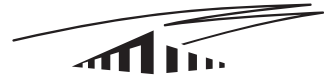

UNIVERSIDADE da MADEIRA

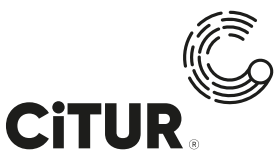

CENTRE FOR TOURISM

RESEARCH, DEVELOPMENT

AND INNOVATION

\author{
Susana Teles \\ University of Madeira, Portugal \\ Catarina Fernando \\ University of Madeira, Portugal \\ Luís Mota \\ University of Madeira, Portugal \\ Mara Franco \\ University of Madeira, Portugal \\ Bruno Gaspar \\ University of Madeira, Portugal \\ Renato Marques \\ University of Madeira, Portugal \\ Sara Vieira \\ University of Madeira, Portugal
}

\section{Paulo Almeida}

CiTUR - Centre for Tourism Research, Development and Innovation

\section{Anabela Almeida}

CiTUR - Centre for Tourism Research, Development and Innovation

\section{João Costa}

CiTUR - Centre for Tourism Research, Development and Innovation

\section{João Paulo C. S. Jorge}

CiTUR - Centre for Tourism Research, Development and Innovation

\section{Verónica Oliveira}

CiTUR - Centre for Tourism Research, Development and Innovation 
TOURISMPHOBIA AND THE RESIDENT-VISITOR RELATIONSHIP: THE CASE OF PORTO (PORTUGAL)..........155

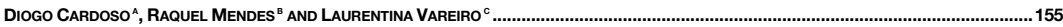
TOURIST ACTIVITIES ARE SHAPING THE IMAGE AND DESTINATION PERSONALITY? THE CASE OF ROMAN HERITAGE SITES IN SERBIA

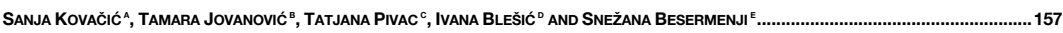

UNDERSTANDING THE ENGAGEMENT IN TOURIST ACTIVITIES OF PEOPLE WITH SPECIAL NEEDS: CONSTRAINTS AND CHALLENGES

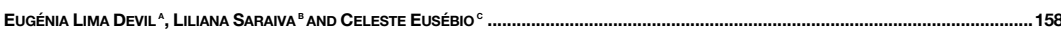

UNESCO BRAND PORTRAIT IN PORTUGAL - THE USE OF THE BRAND ON OFFICIAL WEBSITES .................160

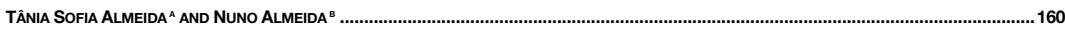

USING DATA ANALYTICS TO UNDERSTAND VISITORS ONLINE SEARCH INTERESTS: THE CASE OF DOURO

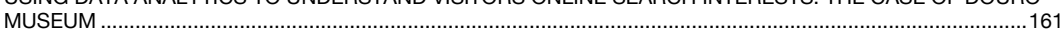

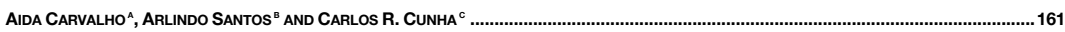

VIRTUAL MUSEUM OF TOURISM (MUVITUR) UNVEILS MADEIRA'S HISTORY OF TOURISM (1930-2000) .......163

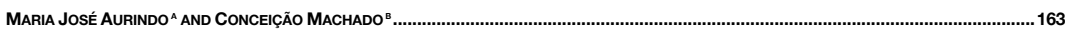

WALKING \& CYCLING ROUTE OF CARSO: SPORT AND TOURIST QUALITY ASSESSMENT ..........................165

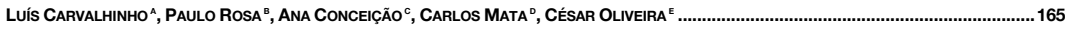


KEYNOTE SPEAKERS - ABSTRACTS

KEYNOTE SPEAKERS

ABSTRACTS 


\title{
USING DATA ANALYTICS TO UNDERSTAND VISITORS ONLINE SEARCH INTERESTS: THE CASE OF DOURO MUSEUM
}

\author{
Aida Carvalho ${ }^{a}$, Arlindo Santos $^{b}$ and Carlos R. Cunha ${ }^{c}$ \\ a CITUR, Instituto Politécnico de Bragança, Portugal \\ acarvalho@ipb.pt \\ b ALGORITMI, Instituto Politécnico de Bragança, Portugal \\ acsantos@ipb.pt \\ c UNIAG, Instituto Politécnico de Bragança, Portugal \\ crc@ipb.pt
}

Regional museums are relatively recent museum structures that emerged in the late 19th century after universal exhibitions. They are museums specifically dedicated to the representation of a given population in a specific territorial context, highlighting the fundamental traits that characterize the nature and essence of that community, differentiating it from others. In northern Portugal, Law no. 125/97 created the Douro Museum, a territory museum that represents the natural and cultural heritage of the demarcated Douro region, the first demarcated and regulated region of the world, in 1756, by Marques de Pombal, extending over an area of of 250,000 hectares, between Barqueiros and Barca d'Alva, along the Douro River and its tributaries. The museum has a "polynuclear structure distributed throughout the Douro region, based in Peso da Régua" (art. 2), serving as an element for mobilizing tourists, mainly through its main temporary exhibitions, videos, etc. In an information society, characterized by the empowerment of citizens with regard to their ability to independently obtain information and, in the process, to leave their footprint, it is crucial to understand and anticipate their interests. In this way, the supply and responsiveness of tourism agents and regional actors will be increased, making them better able to decide for an offer better suited to the real interests of visitors and even enable to influence them.

This article aims to know the profile of tourists / consumers through their online behavior, trying to understand what kind of information they are looking for, which keywords are most used and searched using the fundamentals of Data Analytics and using the Google Trends tool. Moreover, this study enables to better understand the connection between online search interests and the reality of the Douro Museum visitants.

This approach is nowadays a major contribute to bridge the gap between visitors needs/interests and tourism player's strategies definition, making Data Analytics a fundamental tool to enable decision support systems. 
Keywords: Data Analytics, Douro Museum, Google Trends, Tourists, Tourism. 


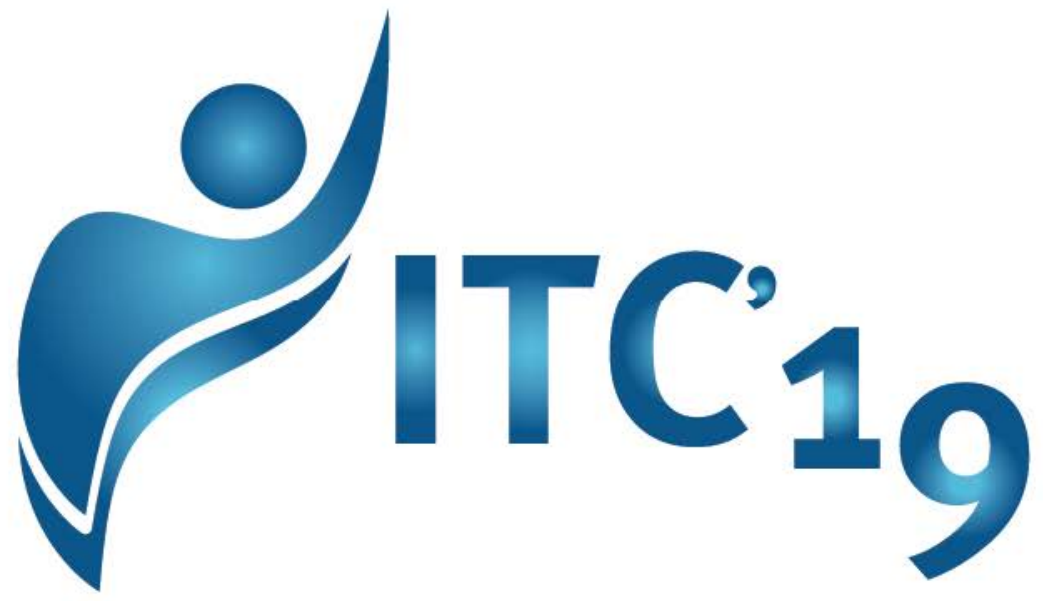

\section{www.citur-tourismresearch.com}

\section{CITUR}

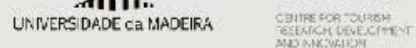

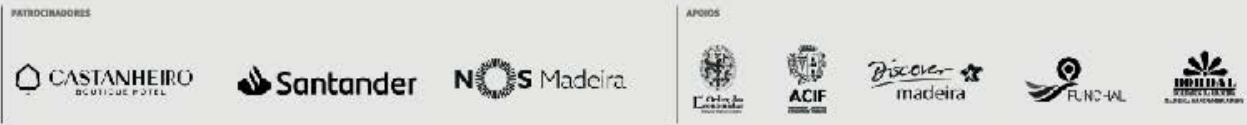

